\title{
THE IMPORTANCE OF PEACE AND STABILITY FOR THE DEVELOPMENT OF SUB-SAHARAN AFRICA
}

\author{
"Development Policy is the Peace Policy of the $21^{\text {st }}$ \\ Century." \\ Willy Brandt \\ "The world has enough for everyone's needs but not for \\ everyone's greed."
}

Mahatma Gandhi

The goal of global development policy is the eradication of poverty. It was formulated in 2000 as one of the Millennium Development Goals, and confirmed in September 2015 at the United Nations Sustainable Development Summit, where a new development agenda for another fifteen years, to 2030, was adopted under the title Transforming Our World: 2030 Agenda for Sustainable Development. The first of seventeen new goals (Sustainable Development Goals - SDGs) is defined as follows: "End poverty in all its forms everywhere" (Transforming, 2015: 14). Politicians and researchers have no doubts that wars and armed conflicts constitute one of the key barriers that hinder efficient combating of poverty. The preamble of the final document of the Summit briefly states: "We are determined to foster peaceful, just and inclusive societies which are free from fear and violence. There can be no sustainable development without peace and no peace without sustainable development" (Transforming, 2015: 1).

The direct correlation between peace and development has been indicated on many occasions before (Promoting democracy, 2005: 41). "Without security, development is fruitless; without development, security is pointless" (Development and Security, 2009: 8). Therefore, many organisations claim that conflict prevention and resolution and increasing stability should constitute prerequisites of development policy (EPPED Development, 2008: 39). Merely securing peace, however, is not a sufficient condition to facilitate development. Amartya Sen observed that "development requires the removal of major sources of unfreedom: poverty as well tyranny, poor economic opportunities as well as systematic social deprivation, neglect of public facilities as well as intolerance or overactivity of repressive states" (Sen, 2000: 3). On the other hand, some researchers are of the opinion that the unfair rules of global trade or climate change, which is primarily triggered by the industries of developed states, are the reasons for new wars as well as the instances of the most acute poverty, including famine. Describing these correlations, such researchers resort to 'military' terminology, for instance Walden Bello - the author of The Food Wars (2009), Harald Welzer - the 
author of Klimakriege (2008) and Jean Ziegler - the author of Destruction massive. Géopolitique de la faim (2011).

The global development agenda encompasses all states of the world, but the level of development achieved by different regions and states is immensely varied. Therefore, the Sustainable Development Goals are of utmost importance for the least developed states and regions. That is why I would like to reflect on what influence armed conflicts and the level of security have on the development of developing countries in Sub-Saharan Africa (SSA). How does the level of security influence development aid in this region?

The correlation of peace and development in Sub-Saharan Africa is twofold. Firstly, Sub-Saharan Africa is the poorest region of the world, as is clearly evidenced by different indicators. According to the 2015 data of the International Monetary Fund, which examined gross domestic product (at purchasing power parity) per capita, out of the twenty poorest countries eighteen were located in SSA.

Table 1

The poorest countries according to the International Monetary Fund

\begin{tabular}{|r|l|c|}
\hline No. & \multicolumn{1}{|c|}{ Country } & Int\$ per capita $^{*}$ \\
\hline 1. & Rwanda & 1,810 \\
\hline 2. & Ethiopia & 1,778 \\
\hline 3. & Kiribati & 1,757 \\
\hline 4. & Haiti & 1,727 \\
\hline 5. & Burkina Faso & 1,650 \\
\hline 6. & Gambia & 1,593 \\
\hline 7. & Sierra Leone & 1,522 \\
\hline 8. & Comoros & 1,511 \\
\hline 9. & Guinea-Bissau & 1,489 \\
\hline 10. & Togo & 1,466 \\
\hline 11. & Madagascar & 1,300 \\
\hline 12. & Eritrea & 1,238 \\
\hline 13. & Guinea & 1,192 \\
\hline 14. & Mozambique & 1,126 \\
\hline 15. & Malawi & 1,077 \\
\hline 16. & Niger & 875 \\
\hline 17. & Liberia & 831 \\
\hline 18. & Burundi & 767 \\
\hline 19. & DR Congo & 628 \\
\hline 20. & Central African Republic & \\
\hline
\end{tabular}

* International dollars.

Source: World Economic Outlook Database, October 2016, International Monetary Fund.

From the point of view of development prospects, the most important target group for global development policy encompasses the Least Developed Countries (LDCs). The first group of LDCs was listed by the UN in resolution 2768 (XXVI) of 18 November 1971. The list of LDCs is reviewed every three years by the UN Economic and Social Council (ECOSOC). The category of LDCs is slightly more complex than the gross domestic product per capita. The following three criteria were used in the most recent review of the list in March 2015: 
- per capita income - "based on a three-year average estimate of the gross national income (GNI) per capita, with a threshold of $\$ 1,035$ for possible cases of addition to the list, and a threshold of $\$ 1,242$ for cases of graduation from LDC status" (The Least, 2016);

- human assets - "involving a composite index (the Human Assets Index) based on indicators of (i) nutrition (percentage of undernourished population); (ii) health (child mortality ratio); (iii) school enrolment (gross secondary school enrolment ratio); and (iv) literacy (adult literacy ratio)" (The Least, 2016);

- economic vulnerability - "involving a composite index (the Economic Vulnerability Index) based on indicators of (i) natural shocks (index of instability of agricultural production; share of victims of natural disasters); (ii) traderelated shocks (index of instability of exports of goods and services); (iii) physical exposure to shocks (share of population living in low-lying areas); (iv) economic exposure to shocks (share of agriculture, forestry and fisheries in GDP; index of merchandise export concentration); (v) smallness (population in logarithm); and (vi) remoteness (index of remoteness)" (The Least, 2016).

Currently, the largest group in this category is made up of SSA countries, accounting for 33 out of 48 states categorised as LDCs in 2016 (ibid.: XIII). The governments of countries taking part in the Third United Nations Conference on the Least Developed Countries, organised in Brussels in May 2001, stated in their Declaration, that they were "determined to make progress towards the global goals of poverty eradication, peace and development for the least developed countries and their people" (Declaration, 2002: 1). The wording here is very diplomatic as the level of determination is difficult, if not impossible to measure. It is equally difficult to measure activity, defined as making "progress towards...". In other words, it is virtually impossible to determine the extent to which UN member states have actually implemented the goals defined in the Brussels Declaration.

Secondly, the number of armed conflicts in Sub-Saharan Africa is larger than in other parts of the world. While Central and Eastern Asia are the area of the most bloody conflicts in terms of casualties, 8 out of 15 conflicts where the death toll exceeded 1,000 in 2015 took place in Africa (including six in Sub-Saharan Africa).

Conflicts with more than 1,000 fatalities (2015)

\begin{tabular}{|r|l|c|}
\hline \multicolumn{1}{|c|}{ No. } & \multicolumn{1}{|c|}{ Country } & Deaths \\
\hline 1 & \multicolumn{1}{|c|}{2} & 3 \\
\hline 1. & Syria & 55,219 \\
\hline 2. & Afghanistan & 36,345 \\
\hline 3. & Iraq & 24,113 \\
\hline 4. & Nigeria & 10,677 \\
\hline 5. & Mexico & 8,122 \\
\hline 6. & Yemen & 6,425 \\
\hline 7. & Pakistan & 4,612 \\
\hline 8. & Ukraine & 4,344 \\
\hline 9. & Somalia & 4,087 \\
\hline 10. & South Sudan & 3,258 \\
\hline
\end{tabular}




\begin{tabular}{|c|l|c|}
\hline 1 & \multicolumn{1}{|c|}{2} & 3 \\
\hline 11. & Sudan & 3,216 \\
\hline 12. & Egypt & 2,836 \\
\hline 13. & Libya & 2,706 \\
\hline 14. & DR Congo & 1,699 \\
\hline 15. & Cameroon & 1,429 \\
\hline
\end{tabular}

Source: Armed Conflict Location \& Event Data Project (ACLED).

There are five more countries in the SSA region with more than 100 fatalities in armed conflicts in 2015: Niger, Central African Republic, Mali, Ethiopia and Burundi. Such a high number of conflicts exerts an influence on the development level of individual countries and the quality of life of their inhabitants, which has further bearing on other indicators and rankings. For instance, the majority of states qualified as 'fragile states' is located in Sub-Saharan Africa. The term 'fragile states' is defined in many different ways. Some of them strongly emphasise the issue of security, as is the case of the Canadian definition in the Country Indicators for Foreign Policy project (CIFP): [fragile states] "lack the functional authority to provide basic security within their borders, the institutional capacity to provide basic social needs for their populations, and/or the political legitimacy to effectively represent their citizens at home or abroad" (Stewart, Brown, 2009: 2). The most popular measure of stability is the Fragile States Index, ${ }^{1}$ developed and calculated by Fund for Peace. This index allows states to be divided into four categories in terms of the level of security: sustainable, stable, warning, and alert. In 2016 the states classified (on the basis of the data for 2015) in the highest category of 'very high alert' encompasses six SSA states: Somalia, South Sudan, Central African Republic, Sudan, Chad and DR Congo. The category of 'high alert' encompasses four states: Guinea, Nigeria, Burundi and Zimbabwe. There are 15 SSA states in the 'alert' category: GuineaBissau, Eritrea, Niger, Kenya, Cote d'Ivoire, Cameroon Uganda, Ethiopia, Liberia, Mauritania, Mali, Congo (Republic), Rwanda, Sierra Leone and Angola. Of the 20 states with the highest Fragile States Index, 14 are within SSA.

Table 3

States with the highest Fragile States Index

\begin{tabular}{|c|l|c|}
\hline No. & \multicolumn{1}{|c|}{ Country } & Fragile States Index (2016) \\
\hline 1 & \multicolumn{1}{|c|}{2} & 3 \\
\hline 1. & Somalia & 114.0 \\
\hline 2. & South Sudan & 113.8 \\
\hline 3. & Central African Republic & 112.1 \\
\hline 4. & Sudan & 111.5 \\
\hline 5. & Yemen & 111.5 \\
\hline 6. & Syria & 110.8 \\
\hline 7. & Chad & 110.1 \\
\hline 8. & DR Congo & 110.0 \\
\hline
\end{tabular}

${ }^{1}$ The Fragile States Index is a ranking of 178 countries based on their levels of stability and the pressures they face. The Index is based on Conflict Assessment Software Tool (CAST) analytical platform. 


\begin{tabular}{|r|l|c||}
\hline 1 & \multicolumn{1}{|c||}{2} & 3 \\
\hline 9. & Afghanistan & 107.9 \\
\hline 10. & Haiti & 105.1 \\
\hline 11. & Iraq & 104.7 \\
\hline 12. & Guinea & 103.8 \\
\hline 13. & Nigeria & 103.5 \\
\hline 14. & Pakistan & 101.7 \\
\hline 15. & Burundi & 100.7 \\
\hline 16. & Zimbabwe & 100.5 \\
\hline 17. & Guinea Bissau & 99.8 \\
\hline 18. & Eritrea & 98.6 \\
\hline 19. & Niger & 98.4 \\
\hline 20. & Kenya & 98.3 \\
\hline
\end{tabular}

Source: Fragile States Index 2016 (2016), The Fund for Peace, Washington.

The international community has been trying to help African states to resolve armed conflicts. The form that is most politically acceptable by African states is provided by peacekeeping missions carried out under UN mandate. Nine out of sixteen UN peace missions are being carried in Africa at present, including the three largest ones in terms of participants. 70,716 out of 85,442 peacekeepers are serving in Africa.

Table 4

UN peacekeeping missions in Africa

\begin{tabular}{|c|l|l|c||}
\hline No & \multicolumn{1}{|c|}{ Mission } & \multicolumn{1}{c|}{ Country/state } & Troops \\
\hline 1. & MONUSCO & DR Congo & 16,735 \\
\hline 2. & UNAMID & Darfur & 13,599 \\
\hline 3. & UNMISS & South Sudan & 12,111 \\
\hline 4. & MINUSMA & Mali & 10,579 \\
\hline 5. & MINUSCA & Central African Republic & 10,245 \\
\hline 6. & UNISFA & Abyei & 4,397 \\
\hline 7. & UNOCI & Cote d'Ivoire & 1,847 \\
\hline 8. & UNMIL & Liberia & 1,179 \\
\hline 9. & MINURSO & West Sahara & 24 \\
\hline
\end{tabular}

Source: UN Peacekeeping missions in Africa, http:/www.un.org/en/peacekeeping/ contributors/2016/aug16_6.pdf(21.12.2016).

A significant proportion of soldiers taking part in UN peacekeeping missions are African. In August 2016 there were 38,861 soldiers from 30 SSA states.

Table 5

States contributing to the UN peacekeeping missions in Africa

\begin{tabular}{|c|l|c|}
\hline \hline No. & \multicolumn{1}{|c|}{ Country } & Troops \\
\hline 1 & 2 & 3 \\
\hline 1. & Benin & 793 \\
\hline 2. & Burkina Faso & 2,530 \\
\hline 3. & Burundi & 829 \\
\hline 4. & Cameroon & 766 \\
\hline 5. & Chad & 1,440 \\
\hline
\end{tabular}




\begin{tabular}{|c|c|c|}
\hline 1 & 2 & 3 \\
\hline 6. & Congo & 628 \\
\hline 7. & Cote d'Ivoire & 7 \\
\hline 8. & Ethiopia & 8,168 \\
\hline 9. & Gabon & 445 \\
\hline 10. & Gambia & 219 \\
\hline 11. & Ghana & 2,446 \\
\hline 12. & Guinea & 861 \\
\hline 13. & Guinea-Bissau & 1 \\
\hline 14. & Kenya & 1,165 \\
\hline 15. & Liberia & 45 \\
\hline 16. & Malawi & 859 \\
\hline 17. & Mail & 2 \\
\hline 18. & Mauretania & 750 \\
\hline 19. & Namibia & 11 \\
\hline 20. & Niger & 1,643 \\
\hline 21. & Nigeria & 1,721 \\
\hline 22. & Rwanda & 5,136 \\
\hline 23. & Senegal & 2,224 \\
\hline 24. & Sierra Leone & 8 \\
\hline 25. & South Africa & 1,359 \\
\hline 26. & Tanzania & 2,244 \\
\hline 27. & Togo & 1,249 \\
\hline 28. & Uganda & 533 \\
\hline 29. & Zambia & 776 \\
\hline 30. & Zimbabwe & 3 \\
\hline
\end{tabular}

Source: UN Peacekeeping missions in Africa, http://www.un.org/en/peacekeeping/contributors/2016/aug16_1.pdf (21.12.2016).

The considerable influence of armed conflicts on development is an outcome, among other things, of very high outlays for conducting conflicts and maintaining armies. Global expenditures for military purposes are many times higher than those for development aid. According to the Stockholm International Peace Research Institute (SPIRI), USD 1,676 bn was spent on defence in 2015 (SIPRI Military Expenditure Database). Global development aid in the same period amounted to USD 146.67 bn according to data from the OECD Development Assistance Committee (DAC). African countries are not leaders in terms of nominal military expenditure, but it is on the rise. Military expenditure went up by 40\% in 1999-2008 (Wulf, 2010: 19). SIPRI estimates that the military expenditure of SSA countries increased from USD 15.9 bn USD to 20.7 bn from 2006 to 2015. This may appear insignificant on a global scale, but compared to the GDP of SSA states it constitutes a considerable outlay. In some cases the level of military expenditure accounts for a very high proportion of GDP.

One of the poorest countries in the world, Eritrea, is the state with the highest military budget in terms of its GDP. It also provides an interesting example of how an armed conflict and the persistent tension in neighbourly relations influences the development of the state. According to SIPRI, there are no reliable data after 2003, when the level of military expenditure accounted for $20.9 \%$ of GDP. 1999 marked a record, with $34.4 \%$ of GDP. This has immensely influenced the structure of state budget expenses. In 2003 , Eritrea spent $31.1 \%$ of its budget for the army, and as much as $47.7 \%$ 
in the record-breaking year 1998. At present, the expenditure for 'defence' is likely to account for approximately $25 \%$ of the budget of one of the poorest countries in the world. Eritrean President, Isaias Afewerki is in constant fear of war with Ethiopia. The entire policy of the state is subordinated to this fear, although it has to be said that this is the policy of a single person, since the President says: "I am the government."2 Presidential policy has an immense influence on how the state and society operate and develop.

The burden related to military service and its practically unlimited duration are among the essential reasons for Eritrean migration to other states. Mandatory military service for men and women was introduced in 1995. Professor Gaim Kibreab of London South Bank University, interviewed 215 former conscripts. They served an average of six and a half years (National service, 2014). Eritreans are the largest group of African refugees trying to enter the European Union (Eurostat). The survey of Prof. Kibreab demonstrates "that thousands of Eritreans flee their country each year primarily to avoid the draft, which they liken to slavery" (National service, 2014). Eritreans do not have too many alternatives to flight, since they "cannot go to university or get a formal job unless they have been officially released from military service. Since conscription became open-ended in 1998, release can depend on the arbitrary whim of a commander, and usually takes years" (National service, 2014).

The tension between Eritrea and Ethiopia has persisted since the three-year war that broke out near Badme in May 1998. Eritrea forcibly conquered an area formerly administered by Ethiopia. The area of contention has neither strategic nor economic significance. Badme is an example of a 'place in the middle of nowhere'. Nevertheless, it has acquired a symbolic significance. ${ }^{3}$ Badme was important for Ethiopia as part of the province of Tigray, the birthplace of a number of members of the government, including the Prime Minister at the time, Meles Zenawi. ${ }^{4}$ President Isaias Afewerki and M. Zenawi happen to come from the same ethnic group, the Tigrinya people. It is ironic, by the way, that Eritrean 'deputy ${ }^{5}$ Mussa Naib, a regular representative of Eritrea at the Joint Parliamentary Assembly of Africa Caribbean Pacific - European Union (JPA ACP-EU) in 2008 was unable to locate Badme on a map. ${ }^{6}$ The primary reason for the still smouldering conflict could not have been too vital if a prominent representative of the regime did not even know where the bone of contention was actually located. It needs to be borne in mind, however, that these are two proud states that will not give up their arguments easily, and war is not an unacceptable alternative to them if it requires fighting to win something important enough. Tesfay Fihira, an Eritrean singer and song writer, happened to sing:

${ }^{2}$ During a meeting with the delegation of the European Parliament in Massawa, October 28, 2008.

${ }^{3}$ According to the ambassador of France to Ethiopia at that time, the battle of Badme claimed 15,000 fatalities. During a meeting with the delegation of the European Parliament in Addis Ababa, October 31, 2008.

${ }^{4}$ Prime Minister of Ethiopia from 1995 till his death in 2012.

5 The 150-seat National Assembly, established initially as a transitional legislature, has never been replaced. It has not met since 2002 .

${ }^{6}$ During a meeting with the delegation of the European Parliament in Asmara, October 27, 2008. 
"Ab kunat gtmat ab zgber e'wan

Ktdfa'e ktdef'e zneberen zeoln

Abti mecheresh nay mrberab gzie gn

Nrebha hzbna k'kewn nay gdn."

Which was translated by Dr Tekeste Fekadu in the following manner:

"Whenever there is war and human conflicts

It is natural to push and be pushed away

However, in the final analysis and in the scheme of things

Victory will always belong to the masses!" (Fekadu, 2002: 306).

The issue of Badme has remained unresolved. After the fighting was concluded, the Eritrea-Ethiopia Boundary Commission, a body founded by the UN, established that Badme belongs to Eritrea, but it is Ethiopia that controls the object of contention. The Ethiopian authorities do not question the decision of the Commission, ${ }^{7}$ but they would like to start improving the relations with their neighbour with dialogue ("dialogue first"). Eritrea, on the other hand wants demarcation first (Report, 2008: 2). The impasse continues, producing the so-called 'no-war-no-peace' situation in Eritrea. Eritrean policy also has an influence on other neighbouring countries. In 2008, Eritrea sparked a border conflict with another neighbour - Djibouti. This had an immediate impact on the finances of Djibouti, a tiny state whose military expenses grew from $1.9 \%$ of GDP (2008) to $3.7 \%$ of GDP (2009) in one year. The relations between Eritrea and yet another neighbour across the Red Sea, Yemen, are also tense. In this case, the bone of contention is the Hanish Islands in the Red Sea. The Eritrean army conquered them after a short battle (December 15-17, 1995). However, in 1998, the Permanent Court of Arbitration in The Hague determined that most of the archipelago belonged to Yemen and the Eritrean troops left the islands. The tension between the two states has remained though.

Armed conflicts exert considerable influence on development. This influence is complex and its impact on development is determined by three primary parameters: the conflict's length, intensity and territorial range. The differences as concerns the scale of each parameter are enormous. The civil war in Angola lasted 27 years from the country regaining independence in 1975 to 2002. The Eritrea-Djibouti border conflict in June 2008 was only several days long, but 35 Djibouti soldiers fell in this brief conflict (Report, 2008: 2). The most bloody conflicts Africa has witnessed were the wars and rebellions in the DRC. The scale of this conflict is confirmed by the fact that the Second Congo War (1998-2003) is sometimes called the African World War and involved the armed forces of eight different states, including Angola, Chad, Namibia and Zimbabwe fighting on the DRC government's side. Rwandan-aligned militias received military aid from Rwanda, Burundi and Uganda. The Second Congo War has been the most bloody conflict since the end of WWII. It brought 5,400,000 fatalities, mainly victims of famine and disease. On the other hand, numerous conflicts in Africa are local, being confined to a single province or locality.

${ }^{7}$ During a meeting with the delegation of the European Parliament with Teshome Toga, Speaker of the House of Representatives, Addis Ababa, October 31, 2008. 
Armed conflicts produce the following outcomes, among other things:

- wounded and fatalities,

- relocation of population (DPs and IDPs),

- psychological problems (rapes, child soldiers, spread of diseases),

- the problem of mined areas,

- reduced or halted agricultural and industrial production,

- reduced or halted commercial exchange,

- damage to technical infrastructure,

- damage to institutional and social infrastructure,

- adverse social phenomena, i.e. piracy,

- environmental damage,

- increased military expenditure,

- risks to food security,

- tarnished image - diminished foreign direct investment.

The ability of different states and regions to overcome the outcomes of armed conflicts depends on a multitude of factors, including the following:

- durability of peace,

- how genuine reconciliation is,

- whether the conditions for ceasefire are perceived as fair,

- pace of reconstruction,

- quality of governance,

- state resources and how diverse budget income is,

- level of state development,

- social level of development (for instance education),

- the extent and timeliness of external support.

It has long been known that armed conflicts exclude development or slow it down. The Swedish-Hungarian analyst, László Szombatfalvy described four megaproblems of our time. Political violence is, in his opinion, one of them. "This includes war, civil war, genocide, forced migration, terrorism and other organized violence with the political objectives" (Szombatfalvy, 2010: 30). In the case of developing countries, one of side effects of war involves increased poverty (ibid.: 30). Research shows that the countries that have suffered from armed conflicts have had less chance to implement the goals indicated by the global development agenda within the Millennium Development Goals (Debiel, Werthes, 2007: 37). The first European Report on Development drafted as a result of the "Mobilising European research for development policies" initiative was entirely dedicated to the issue of Overcoming Fragility in Africa. The Report was developed by the European University Institute (EUI) in Florence and it confirmed that "fragility is clearly associated with much poorer development outcomes in terms of poverty, undernutrition, education enrolment and under five mortality" (European Report, 2009: 20).

The impact of conflicts on development is also confirmed by the fact that the states where armed conflicts have not occurred achieve better human development indexes (ibid.: 42). According to the UN, out of 20 states with the lowest Human Development Index (HDI) 19 are located in Sub-Saharan Africa. 
Table 6

States with the lowest Human Development Index

\begin{tabular}{|c|l|c|}
\hline No. & \multicolumn{1}{|c|}{ Country } & HDI (2015) \\
\hline 169. & South Sudan & 0.467 \\
\hline 170. & Senegal & 0.466 \\
\hline $17 .$. & Afghanistan & 0.465 \\
\hline 173. & Ivory Coast & 0.462 \\
\hline 174. & Malawi & 0.445 \\
\hline 175. & Ethiopia & 0.442 \\
\hline 176. & Gambia & 0.441 \\
\hline 177. & DR Congo & 0.433 \\
\hline 178. & Liberia & 0.430 \\
\hline 179. & Guinea-Bissau & 0.420 \\
\hline 180. & Mali & 0.419 \\
\hline 181. & Mozambique & 0.416 \\
\hline 182. & Sierra Leone & 0.413 \\
\hline 183. & Guinea & 0.411 \\
\hline 184. & Burkina Faso & 0.402 \\
\hline 185. & Burundi & 0.400 \\
\hline 186. & Chad & 0.392 \\
\hline 187. & Eritrea & 0.391 \\
\hline 188. & Central African Republic & 0.350 \\
\hline 189. & Niger & 0.348 \\
\hline
\end{tabular}

Source: Human Development Report 2015 Sustaining Human Progress: Reducing Vulnerabilities and Building Resilience (2015), United Nations Development Programme (UNDP), New York.

Only a few of these African states (Malawi and Gambia) have not experienced armed conflicts in the $21^{\text {st }}$ century.

In the opinion of numerous researchers, the poor development of SSA states is the outcome of their leaders' inability to impose and maintain efficient rule (Meredith, 2011: 610). The prerequisite of efficient governance, however, is provided by security. James Putzel maintained: "The first step in state-building is establishing security, without which no amount of good governance or development assistance can effectively prevent collapse" (Development and Security, 2009: 30). African leaders have a similar attitude to the hierarchy of tasks. In an interview for "Foreign Affairs," Senegalese President Macky Sall said: "We have to ensure the security of our populations, the inviolability of our borders, and the stability of our states so that we can focus on such issues as development and poverty" (Africa's Turn, 2013: 5). Thus, state-building should be the primary goal of international involvement in unstable countries, as stated in the Principles for Good International Engagement in Fragile States and Situations, developed by DAC OECD in 2007.

South Sudan offers a good example of this mechanism. This state, which is the youngest state in the world, was one of the so-called 'aid darlings' of donors when becoming independent in July 2011. Between 2011 and 2012 South Sudan received US\$ 2.7 bn in official development assistance (ODA). Additionally in 2012, South Sudan received US\$ $865 \mathrm{mln}$ in international humanitarian assistance, making it the second largest recipient (Global Humanitarian Assistance. A Development Initiative). 
South Sudan should have been able focus on development. Unfortunately, as early as one month after the declaration of independence, in August 2011, tribal fighting broke out in South Sudan, and we can even talk about a full-blown civil war since December 2013. Many thousands of victims are estimated to have died in its wake. In August 2015 the fighting parties signed another truce, but there is no way of telling whether it is going to work. So far, the violence and fatalities have not been stopped.

The fighting had a tragic and devastating influence on the young state. The number of internally displaced people (IDPs) was estimated at over 1.87 million in December 2016. (OCHA). Before the civil conflict broke out, South Sudan had positive development prospects. At present, the "challenges of the civil conflict are compounded by enormous economic and fiscal problems. The government budget is facing a huge shortfall caused by the sharp decline in oil revenues" (African, 2016: 316). South Sudan has the second highest score on the Fragile States Index (2016). One of the outcomes of the civil war, combined with a poor harvest in 2015 was that millions people who live there were "severely food insecure" or unable to produce or purchase adequate food. According OCHA: "[s]ome 3.7 million people in South Sudan are estimated to be severely food insecure from October to December 2016, the highest levels experienced at harvest time and an increase of 1 million people compared to the same period last year. Food insecurity is likely to worsen from January to April 2017 and is expected to peak during the lean season from May to July 2017 to the highest levels ever seen in the lean period" (Humanitarian, 2016: 1). The state's ambitious development agenda was halted by the internal conflict, which paralyses a state also facing a number of other difficulties.

It is an important issue of development policy how to respond to the dilemma of whether development aid may in some cases fuel conflicts, regardless of the donors' intentions. The greatest conflict of the $21^{\text {st }}$ century so far was the war in the Democratic Republic of Congo. Jason K. Stearns, director of the Usalama Project ${ }^{8}$ expressed his $^{-}$ views on one of the conspiracy theories as regards the fighting there. The theory is founded on the assumption that the donors were allegedly interested in the 'Balkanisation' of the DRC, in order to exploit the mineral resources of the country more easily and cost-efficiently. One of the arguments employed by the advocates of this theory is to ask why else would the donors finance nearly half of the budgets of DRC and Rwanda for the last decade. Stearns answers this question differently: "it is apathy and ignorance, not hegemonic ambitions, that donors are guilty of. Congo does not rank in the top tier of foreign policy priorities in London, Paris, Washington, or Beijing" (Stearns, 2013: 102). I support this view. For years, numerous politicians, officials and representatives of international institutions have declared Africa the priority in terms of security. This frequently is wishful thinking, though. Alvaro de Vasconcelos, director of the EU Institute for Security Studies wrote in 2007 that the "African continent is gradually becoming a priority area for the European Union [...] After many years in which the emphasis was on development aid and, to some extent, good governance, the over-riding message today is clearly that without security human development is not sustainable" (Vasconcelos, 2007: 10). I do not believe that security is the true priority

\footnotetext{
${ }^{8}$ A research programme on Congolese armed groups at the Rift Valley Institute.
} 
driving donors today. However they do learn some lessons from such cases as that of the DRC, where successive waves of violence annihilated the outcomes of development aid. In 2012, donors suspended budget support for Rwanda after it supported the M23 rebellion in the DRC (Stearns, 2013: 111-112).

On the other hand, the fears that development aid may potentially prolong conflicts, combined with intensifying endeavours to increase the efficiency of aid (so that development aid yields planned and measurable outcomes) make fragile states 'aid orphans' at the same time. This mechanism is about donors withdrawing from the states offering smaller chances of achieving expected and measurable goals than those potentially attainable in stable countries, where they could be additionally held accountable for prolonging conflicts. The above-quoted Overcoming Fragility in Africa report observes that "[d] onors can even hinder the transition from fragility. Indeed, aid flows - excluding technical assistance - can reduce the likelihood of exiting from the group of fragile countries. Such a finding, echoed by Dambisa Moyo in her bestselling «Dead Aid», signals room for improving international engagements with fragile countries" (European Report, 2009: 12).

There are tools to examine the 'growth-efficient' level of aid. Mark McGillivray, from the Australian Agency for International Development defines this level as follows: "the incremental relationship between aid and growth follows an inverted U-shaped pattern, with higher levels of aid associated with higher rates of growth up to a certain threshold level of aid, beyond which more aid is associated with lower growth" (European Report, 2009: 13). This is how this relationship can be graphically presented.

Figure 1. Incremental impacts of aid on growth

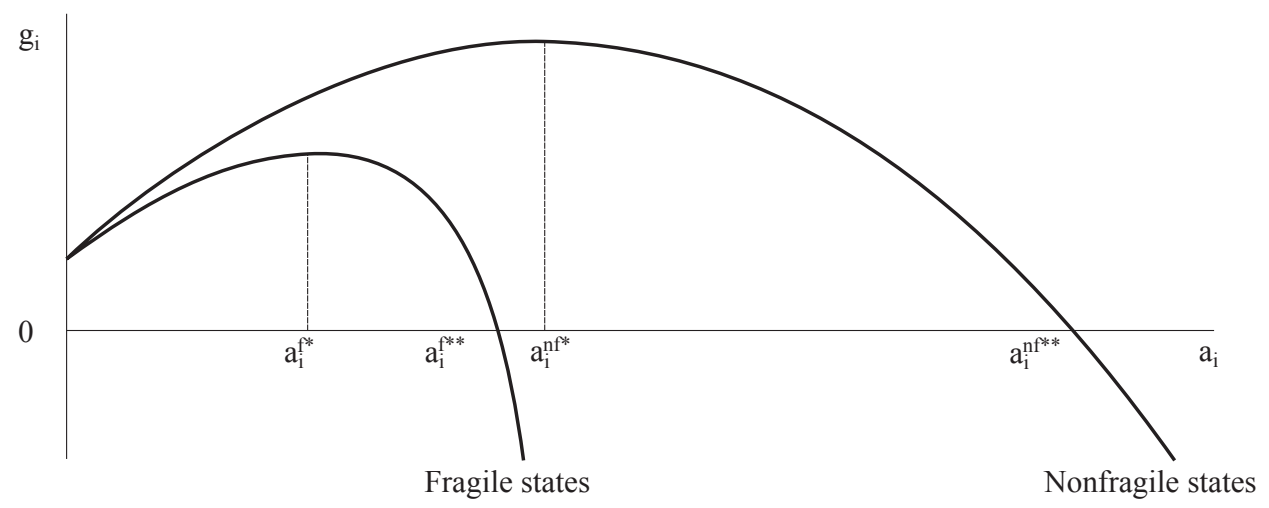

Note: aid refers to some measure of aid to recipient country $i$, gi refers to i's real per capita GDP growth, $a_{i}^{\text {n* }}$ is the growth efficient level of aid for non-fragile states, and $a_{1}^{\mathrm{n}^{\mathrm{p*} *}}$ is the level of aid beyond which the incremental contribution of aid to growth in these states is negative.

Source: European Report on Development (2009).

McGillivray observes: "The finding of an inverted U-shaped relationship between aid and growth has particular resonance for fragile states. An interpretation of the declining incremental impact of aid, beyond the growth-efficient level, is that there are absorptive capacity constraints in recipient countries" (European Report, 2009: 13). 
This knowledge is not applied in practice by donors. In terms of efficiency, some fragile states receive insufficient aid while others get too much.

Another political challenge concerns the fact that African states are unable to resolve conflicts and re-establish security by themselves. In the above-mentioned interview, President Macky Sall said that "Africa cannot handle its own problems, because we are not yet at the point where we have the logistical capabilities to deploy troops in case of emergency. It's simply a matter of means, not a matter of men" (Africa's Turn, 2013: 5). The issue is not always as straightforward, however, as the President sees it. Sometimes African states lack the political will to intervene. In other cases, the main stimulus to intervene in another country is not the concern for its stability but rather the short-term political or strategic interests of the intervening state. Sometimes there is no intention of becoming politically involved. For instance, the $15^{\text {th }}$ Africa Caribbean Pacific (ACP) - European Union Joint Parliamentary Assembly in Ljubljana (Slovenia) in March 2008 failed to adopt a motion for a resolution on developments in Chad. The draft was rejected because it failed to win sufficient backing from the ACP side. The Assembly allows ACP and EU delegates to vote in their respective delegations, which means that if a project is to be adopted, it is required to win a majority of votes in either delegation. The delegates from francophone Africa succeeded in persuading a majority of ACP delegates not to adopt any resolution on Chad at the Assembly. Members of the European Parliament were disappointed with the attitude of their African partners, which they interpreted as 'burying heads in the sand.'

Donors realise that in order to resolve the conflicts once and for all, it is necessary to eliminate the reasons for these conflicts. At the same time, however, not every donor wants, or is able to become involved in military interventions aiming at restoring peace. Other donors intervene quite frequently, but they typically do it in states where they have developed special relations. Most often this concerns their former colonies, or countries with strong economic, cultural and political ties. Individual EU member states have taken part in military interventions in Africa dozens of times. France alone has carried out over 30 military interventions in post-colonial Africa (Huliaras, 2009: 35). The EU, which is an important donor, however, made the first decision about deploying its troops outside Europe as late as in 2003, when it approved the Artemis mission, aiming to stabilise Ituri province (DRC). It has to be borne in mind that achieving a ceasefire and restoring peace alone does not suffice to eliminate the reasons for conflicts. Stearns writes that "[i]t is easier to fix roads and train police than change the deep-rooted incentives and habits of those in power in the region. Donors have learned that lesson in Afghanistan, another place where corrosive patronage politics, cross-border meddling, and a fragmented political landscape have perpetuated violence" (Stearns, 2013: 112).

Different groups of politicians and experts try to address the difficult dilemma of how to ensure peace and greater stability to developing states. Considerable attention was given to the matters of security at the second European Union-Africa Summit in Lisbon (December 8-9, 2007), where three documents were adopted: Lisbon Declaration, The Joint Africa-Europe Strategy (JAES) and The First Action Plan for the period 2008-2010, aiming to implement strategic partnership between Africa and the EU in practice. All three documents address the issue of peace and security. What makes 
JAES unique is that it is a truly joint strategy. For the first time the European vision of African development did not emerge as a unilateral act but was produced in the course of negotiations between the interested parties.

The prominent goal of EU-African partnership indicated by the Lisbon Declaration was "peace and stability". Out of the four main objectives established in JEAS, three encompassed fields related to peace. The first objective stated that the partnership seeks "strengthening of institutional ties and addressing common challenges, in particular peace and security" (The Africa-European Union, 2008: 14). The second one directly referred to strengthening and promotion of "peace, security, democratic governance and human rights, fundamental freedoms, gender equality, sustainable economic development, including industrialization, and regional and continental integration in Africa [...]" (The Africa-European Union, 2008: 14). The list of values to be promoted was anything but short, but it was not by coincidence, in my opinion, that peace and security were at the top. The third objective was "to promote and sustain effective multilateralism, with strong, representative and legitimate institutions [...]" (The Africa-European Union, 2008: 14). These institutions were to address an extensive range of issues in need of resolving, including "the proliferation of Weapons of Mass Destruction and the illicit trafficking of Small Arms and Light Weapons" (The Africa-European Union, 2008: 14).

The largest part of JEAS is devoted to describing four directional strategies. The first one concerns "peace and security." The heads of states and governments clearly declared that "Africa and Europe understand the importance of peace and security as preconditions for political, economic and social development. They supported holistic approaches to security, encompassing conflict prevention and long-term peace-building, conflict resolution and post-conflict reconstruction, linked to governance and sustainable development, with a view to addressing the root causes of conflicts." Another goal of the strategy was to design a mechanism of peace-making, peace-keeping and peace-building. It was named the African Peace and Security Architecture (APSA). All the strategic objectives defined in the directional strategies were to be implemented via eight thematic partnerships, described in The First Action Plan for the period 20082010. The first partnership was the Africa-EU Partnership on Peace and Security. Regardless of the efforts of both parties, the situation in terms of security in Africa has not improved since 2007. Peace and security remain one of the main themes of cooperation between Africa and the European Union. The leading topic of the $4^{\text {th }}$ Africa-EU summit, held in Brussels on April 2-3, 2014, was "investing in people, prosperity and peace."

The issue of how security influences the development of African states has also been the subject of interdisciplinary academic research. Scholars try to forecast what can be done in order to improve the situation in this respect. The authors of the first European Report on Development have indicated five priorities related to African instability. Although addressed at the EU, these priorities are universal. This time, security can be found at the bottom of the list:

- supporting state-building and social cohesion;

- overcoming the divide between short-term needs and long-term resilience;

- enhancing human and social capital; 
- supporting better regional governance, including regional integration processes;

- promoting security and development (European Report, 2009: 7).

In May 2014, members of the Independent Vision Group on European Development Cooperation ${ }^{9}$ published a document titled Re-Shaping Global Development: Will Europe Lead? An Argument and a Call to Action. This was an attempt at defining the role the EU should play in global development cooperation. As concerns fragile states, the authors believed that "[a]t present, too much depends on the resolve of the rare member states willing to engage themselves in peace operations with uncertain time frames and outcomes. A more coordinated approach is needed" (Re-Shaping, 2014: 10). They also tried to narrow down the extensive list of priorities or conditions for development. Consequently, the Independent Vision Group strongly emphasised the relation between security and respect for human rights: "Respect for human rights leads to long term stability. Inversely, the denial of universal rights eventually leads to the collapse of governments and economics" (ibid.: 10). This diagnosis seems accurate. It is more difficult to implement than to diagnose, though. Key donors, such as the EU, have considerable difficulty both becoming involved in peacekeeping missions and improving coordination as well as convincing its African partners to truly acknowledge the universal character of human rights in their Euro-Atlantic interpretation. Other academic and political concepts typically encounter the same obstacle - that of implementation.

$* * *$

This analysis of the situation of SSA states shows that it is impossible to achieve permanent, sustainable development in the conditions of war or other military conflicts. External aid for such countries is first and foremost humanitarian aid. Although such aid is necessary and helps save human lives, it does not eliminate the reasons for conflicts and is unable to ensure stable development. In the states with the worst situation, humanitarian aid does not have a significant influence on reducing migration trends. Before permanent development occurs, conflicts have to be efficiently resolved and their reasons eliminated or radically limited. The social and economic development of SSA states, which are currently suffering from armed conflicts and instability, is therefore primarily dependent on political rather than economic solutions.

\section{BIBLIOGRAPHY}

Africa's Turn. A Conversation With Macky Sall (2013), "Foreign Affairs", Vol. 92, No. 5, September/ October, New York.

African Economic Outlook (2016), African Development Bank, OECD Development Centre, UNDP, http://www.afdb.org/fileadmin/uploads/afdb/Documents/Publications/AEO_2016_Report_ Full_English.pdf (21.12.2016).

${ }^{9}$ Members of the Independent Vision Group: Thijs Berman, Bengt Braun, Baroness Margaret Jay, Filip Kaczmarek, Louka Katseli, Simon Maxwell, Dirk Messner, Ana Palacio, Laurence Tubiana, Kevin Watkins, Mikaela Gavas. 
Debiel T., Werthes S. (2006), Fragile States and Peace-building, in: Global Trends 2007. Vulnerability and Human Security in the $21^{\text {st }}$ Century, (eds.) T. Debiel, D. Messner, F. Nuscheler, Development and Peace Foundation, Bonn.

Declaration and Programme of Action for the Least Developed Countries for the Decade 2001-2010 (2002), United Nations, New York.

Development and Security: Two sides of the same coin. Report of the seventh Development Policy Forum (DPF) roundtable (2009), Friends of Europe, Brussels.

EPP-ED Development Charter. 100 points for a better world (2008), EPP-ED Group in the European Parliament, Brussels.

EU Development Cooperation in Fragile States: Challenges and Opportunities. Study (2013), European Parliament, Brussels.

European Report on Development 2009. Overcoming Fragility in Africa (2009), Robert Schuman Centre for Advanced Studies, European University Institute, San Domenico di Fiesole.

Fekadu T. (2002), Journey from Nakfa to Nakfa. Back to Square One 1976-1979. Inside Eritrea's War for Independence, Sabur Printing Services, Asmara.

Fragile States Index 2016 (2016), The Fund for Peace, Washington.

"Humanitarian Bulletin South Sudan", Issue 19, 6 December 2016, http://reliefweb.int/report/southsudan/south-sudan-humanitarian-bulletin-issue-19-6-december-2016 (21.12.2016).

Huliaras A. (2009), EU-Africa Relations: Dealing with the Challenges of the Future, Centre for European Studies, Brussels.

Meredith M. (2011), Historia współczesnej Afryki. Pół wieku niepodległości, Warszawa.

National service in Eritrea. Miserable and useless (2014), "The Economist", 10.03.2014.

Promoting Democracy. Creating Peace. Shaping Globalisation (2005), The Friedrich-Ebert-Stiftung, Bonn.

Report on the Fact-find Mission to the Horn of Africa (Eritrea, Djibouti, Ethiopia) (2008), Committee on Development, European Parliament, Brussels.

Re-Shaping Global Development: Will Europe Lead? An Argument and a Call to Action (2014), The Independent Vision Group on European Development Cooperation, Brighton.

Sen A. (2000), Development as Freedom, New York.

Sidriopoulos E., Chevallier R. (2006), The European Union and Africa: Developing Partnerships for Peace and Security, The South African Institute of International Affairs, Johannesburg.

Stearns J. K. (2013), Helping Congo Help Itself. What It Will Take to end Africa's Worst War, "Foreign Affairs", Vol. 92, No. 5, September/October, New York.

Stewart F., Brown G. (2009), Fragile States, “CRISE Working Paper”, No. 51, Centre for Research on Inequality, Human Security and Ethnicity (CRISE), Oxford.

Szombatfalvy L. (2010), The Greatest Challenges of Our Time, Stockholm.

The Africa-European Union Strategic Partnership (2008), Council of the European Union, Brussels.

The Least Developed Countries Report 2016. The path to graduation and beyond: Making the most of the process (2016), United Nations Conference on Trade and Development, New York and Geneva, http://unctad.org/en/PublicationsLibrary/ldc2016_en.pdf (21.12.2016).

Transforming our world: the 2030 Agenda for Sustainable Development. Resolution adopted by the General Assembly on 25 September 2015. A/RES/70/1, United Nations, New York.

White J. M. (2009), No Development without Security. The transatlantic donor community needs to redesign aid for fragile states, Brussels Forum Paper Series, The German Marshall Fund of the United States, Washington. 
Wulf H. (2010), Military Security between Rearmament, Democratisation and Privatisation, in: Global Trends 2010. Peace-Development-Environment, (eds.) T. Debiel, D. Messner, F. Nuscheler, M. Roth, C. Ulbert, Development and Peace Foundation, Bonn.

Vasconcelos de A. (2007), Security for Africans, "European Security and Defence Policy Newsletter", No. 5, Council of The European Union, Bruxelles.

\begin{abstract}
This analysis of the situation of Sub-Saharan Africa states shows that it is impossible to achieve permanent, sustainable development in the conditions of war or other military conflicts. External aid for such countries is first and foremost humanitarian aid. Although such aid is necessary and helps save human lives, it does not eliminate the reasons for conflicts and is unable to ensure stable development. In the states with the worst situation, humanitarian aid does not have a significant influence on reducing migration trends. Before permanent development occurs, conflicts have to be efficiently resolved and their reasons eliminated or radically limited. The social and economic development of SSA states, which are currently suffering from armed conflicts and instability, is therefore primarily dependent on political rather than economic solutions.
\end{abstract}

Keywords: Sub-Saharan Africa, development, military conflicts, instability

\title{
ZNACZENIE POKOJU I STABILIZACJI DLA ROZWOJU AFRYKI SUBSAHARYJSKIEJ
}

\section{STRESZCZENIE}

Z analizy sytuacji państw Afryki Subsaharyjskiej wynika, że trwały, zrównoważony rozwój w warunkach wojny czy innych konfliktów zbrojnych nie jest możliwy. Pomoc z zewnątrz ma w tych krajach przede wszystkim charakter pomocy humanitarnej. Jest ona potrzebna i ratuje ludzkie życie. Sama w sobie nie likwiduje jednak przyczyn konfliktów ani nie jest w stanie zapewnić trwałego rozwoju. W przypadku państw o najgorszej sytuacji, pomoc humanitarna nie wpływa też w istotny sposób na zmniejszenie tendencji migracyjnych. Budowanie trwałego rozwoju musi być poprzedzone skutecznym zakończeniem konfliktów oraz wyeliminowaniem lub radykalnym ograniczeniem ich przyczyn. Rozwój społeczny i gospodarczy państw Afryki Subsaharyjskiej, doświadczających konfliktów zbrojnych i niestabilności jest zatem uzależniony w pierwszej kolejności od rozwiązań politycznych, a nie ekonomicznych.

Słowa kluczowe: Afryka Subsaharyjska, rozwój, konflikty zbrojne, niestabilność 
